MaPan : Jurnal Matematika dan Pembelajaran

p-ISSN: 2354-6883 ; e-ISSN: 2581-172X

Volume 7, No 2, December 2019 (328-341)

DOI: https://doi.org/10.24252/mapan.2019v7n2a11

\title{
KEMAMPUAN MENERJEMAHKAN EKSPRESI ALJABAR DITINJAU DARI KECERDASAN MAJEMUK SISWA
}

\author{
Hartono1), Nadya Febriani'2), Iwit Prihatin ${ }^{3)}$ \\ 1,2,3IKIP PGRI Pontianak \\ 1,2,3 Jalan Ampera No 88 Kota Pontianak \\ E-mail: andra.hartono@gmail.com ${ }^{1}$, nadyafebriani02@gmail.com ${ }^{2}$, \\ iwitprihatin82@gmail.com ${ }^{3}$ )
}

Submitted: 08-10-2018, Revised: 02-01-2019, Accepted: 21-11-2019

\begin{abstract}
Abstrak:
Penelitian ini bertujuan untuk mendeskripsikan kemampuan menerjemahkan ekspresi aljabar siswa ditinjau dari kecerdasan majemuk. Pemahaman siswa dapat dilihat dari kemampuan menerjemahkan, dalam hal ini kecerdasan yang diteliti hanya empat ranah yaitu: kecerdasan linguistik, logika matematika, visual-spasial dan kecerdasan interpersonal. Jenis penelitian yang digunakan adalah kualitatif dengan rancangan penelitian studi kasus menggunakan pendekatan deskriptif. Subjek dalam penelitian ini adalah 22 siswa kelas VII A SMP Negeri 15 Pontianak Tahun Ajaran 2016/2017. Instrumen penelitian adalah angket dan tes. Prosedur analisis data menggunakan tiga tahap yaitu: (1) reduksi, (2) penyajian data, (3) pengambilan keputusan atau verifikasi. Hasil penelitian yang diperoleh adalah ratarata nilai yang diperoleh siswa dengan kecerdasan linguistik sebesar 91,66 kategori amat baik, kecerdasan logika matematika sebesar 59,99 kategori kurang, visualspasial sebesar 68,74, dan kecerdasan interpersonal sebesar 59,93 kategori kurang.
\end{abstract}

Kata Kunci: Kemampuan Menerjemahkan, Ekspresi Aljabar, Kecerdasan Majemuk

\section{THE STUDENTS' ABILITY TO SOLVE MATHEMATICS PROBLEMS THROUGH HIGHER ORDER THINKING SKILLS EXERCISES}

\begin{abstract}
:
The purpose of this research was to describe the students' ability in explaining algebraic expressions in terms of multiple intelligences. The students' understanding could be seen from the ability to explain, in this case the intelligence studied was only four domains, namely: linguistic intelligence, mathematical logic, visual-spatial and interpersonal intelligence. The research method used was qualitative with descriptive approach. The research instruments were questionnaire and test. The analysis procedures used three steps: (1) reduction, (2) presenting the data, (3) deciding or verification. The subject in this research was 22 students of class VII A in SMPN 15 Pontianak Academic Year of 2016/2017. The result obtained was the average values which included very good criteria (91.66) in linguistic intelligence, less (59.99) in mathematical logic intelligence, 68.74 in visual-spatial, and less criteria (59.93) in interpersonal intelligence.
\end{abstract}

Keywords: Ability to Explain, Algebraic Expressions, Multiple Intelegences

Copyright ( 2019, MaPan : Jurnal Matematika dan Pembelajaran 
How to Cite: Hartono., Febriani, N., \& Prihatin, I. (2019). Kemampuan menerjemahkan ekspresi aljabar ditinjau dari kecerdasan majemuk siswa. MaPan: Jurnal Matematika dan Pembelajaran, 7(2), 328-341.

\section{PENDAHULUAN}

$\mathrm{M}$

atematika adalah hal yang abstrak, untuk mempermudah mempelajarinya dibutuhkan kemampuan yang dapat mendukung siswa. Dalam KBBI (2008: 909), kemampuan berasal dari kata "mampu" yang berarti kuasa (bisa, sanggup, dapat melakukan sesuatu). Itu artinya kemampuan adalah kesanggupan atau kecakapan seorang individu dalam menguasai suatu keahlian dan digunakan untuk mengerjakan beragam tugas dalam suatu pekerjaan. Pada hakikatnya kemampuan manusia itu berbeda-beda dikarenakan kita memiliki tingkat kecerdasan yang berbeda pula. Sejalan dengan itu, Gardner dalam Armstrong (2009) mengatakan bahwa "kita semua begitu berbeda terutama karena kita semua memiliki kombinasi yang berbeda dalam kecerdasan".

Kecerdasan sering diartikan sebagai kemampuan seseorang dalam proses berpikir. Proses berpikir disini dilakukan untuk memperoleh suatu pengetahuan yang lebih dalam. Pengetahuan yang diperoleh sebagai landasan untuk mencapai keberhasilan. Banyak yang menganggap bahwa orang yang mempunyai kecerdasan intelektual akan memperoleh keberhasilan. Namun, keberhasilan seseorang tidak hanya ditentukan dari kecerdasan intelektualnya saja, tetapi ada dukungan dari kecerdasan lain. Ada delapan kecerdasan yang terdapat dalam diri manusia yaitu kecerdasan linguistik, logika matematika, visual-spasial, musikal, interpersonal, intrapersonal, natural, dan kinestetik. Sejalan dengan itu, Garnder dalam Armstrong (2009) mengatakan bahwa kecerdasan adalah "tersedianya sarana pemetaan berbagai kemampuan manusia dengan mengelompokkan kemampuan mereka menjadi delapan kecerdasaan yaitu, kecerdasan linguistic, logical mathematical, visual-spatial, bodily kinesthetic, musical, interpersonal, intrapersonal, dan kecerdasan naturalist." Maka dari itu, setiap manusia tidak dapat disamakan tingkat kecerdasannya. Hal tersebut pula yang menyebabkan kemampuan antara manusia satu dengan manusia lainnya berbeda.

Masing-masing kecerdasan tersebut tentu juga memiliki keunikan tersendiri dalam memaknai suatu permasalahan yang ditemui terutama dalam merepresentasikan dengan kemampuan berbeda-beda, seperti yang 
dilaporkan dalam penelitian Asyrofi \& Junaedi (2016). Seorang individu melakukan pemaknaan secara mental untuk memperoleh suatu pemahaman. Pemahaman yang diperoleh terkadang digunakan sebagai pengetahuan untuk disimpan dalam memori atau dikomunikasikan dalam bentuk representasi yang sama atau berbeda dari kondisi atau fenomena awal. Pemaknaan dan pemahaman dengan representasi yang berbeda khusus simbol atau gambar ke dalam bentuk verbal disebut translasi atau menerjemahkan.

Menerjemahkan adalah sebuah aktivitas yang secara jelas melibatkan dua bahasa. Dalam menerjemahkan sebuah bahasa tulisan ke dalam bahasa yang lain harus sesuai dengan yang dimaksudkan penulis dan tidak merubah makna dari bahasa itu sendiri. Dalam KBBI (2008: 1509), menerjemahkan berasal dari kata "terjemah" yang artinya menyalin (memindahkan) suatu bahasa ke bahasa yang lain. Dalam dunia pendidikan, penting bagi siswa untuk memiliki kemampuan dalam menerjemahkan, terlebih dalam pembelajaran matematika, karena matematika bukan hanya sekedar hitungan atau identik dengan rumus-rumus yang telah disepakati oleh para matematikawan. Akan tetapi, matematika juga merupakan bahasa. Bahasa matematika berupa simbol-simbol maupun lambang-lambang. Pemahaman terhadap simbol tersebut adalah kunci utama dalam memahami bahasa matematika. Akhirnya, bahasa matematika tersebut berguna dalam pemecahan masalah dalam kehidupan sehari-hari karena pemahaman tersebut diterjemahkan ke dalam bahasa matematika dalam model matematika. Menurut Daryanto dalam Desy (2016), pengertian menerjemahkan bukan saja pengalihan (translation) arti dari bahasa satu ke dalam bahasa yang lain. Dapat juga menjadi konsepsi abstrak menjadi suatu model, yaitu model simbolik untuk mempermudah orang mempelajarinya.

Salah satu cabang dari matematika adalah aljabar. Aljabar sering kali ditemui dalam permasalahan di kehidupan sehari-hari terutama dalam bidang ekonomi. Aljabar selalu digunakan untuk mendapatkan hasil dan keputusan yang baik. Mempelajari aljabar tentu memiliki banyak manfaat, maka dari itu pelajaran aljabar sering siswa temukan ketika belajar di kelas, namun masih banyak siswa yang belum mengenal bahkan mengetahui tentang materi aljabar. Aljabar sering dianggap sebagai pelajaran yang sulit ditaklukkan bahkan tidak sedikit yang membenci aljabar. Ekspresi aljabar merupakan bahasa simbol dan relasi. Menurut Jonhson \& Rising dalam Krismanto (2009), aljabar digunakan untuk memecahkan masalah sehari - hari. Dengan bahasa simbol, dari relasi- relasi yang muncul, masalah-masalah dipecahkan secara 
sederhana. Belajar aljabar bukan hanya belajar tentang simbol-simbol melainkan tentang masalah sehari-hari. Pengalihan konsep yang dirumuskan dengan kata-kata menjadi simbol aljabar termasuk dalam kategori menerjemahkan. Jadi, kemampuan menerjemahkan ekspresi aljabar ialah kepandaian siswa mengubah kata-kata ke dalam bentuk simbol-simbol tanpa mengubah makna dari kalimat tersebut. Ekspresi aljabar jarang digunakan dalam istilah matematika, biasanya kata-kata yang digunakan adalah bentuk aljabar.

Berdasarkan observasi dalam rangka pra-riset diperoleh bahwa rata-rata nilai ulangan harian siswa kelas VII masih di bawah standar ketuntasan dalam menyelesaikan soal yang berkaitan dengan aljabar. Fakta di lapangan, siswa masih kesulitan untuk menerjemahkan bahasa aljabar ke dalam ekspresi aljabar. Contoh seperti soal cerita berikut ini: Danu membeli tiga permen kopiko dengan empat buah apel. Setelah sampai di rumah, satu permen dan dua buah apel diberikan pada adiknya. Berapa sisa permen dan buah apel yang dimiliki Danu?. Contoh soal cerita tersebut mengambil konsep operasi pengurangan dengan menggunakan model permen kopiko dan buah apel. Soal tersebut sebenarnya bisa diganti dengan suatu bentuk variabel. Dari contoh tersebut, siswa diharapkan mampu mengomunikasikan atau menuangkan ide-ide dasar matematika secara tertulis. Meskipun dengan cara atau aturan yang belum tentu sesuai dengan ekspresi aljabar dan matematis. Misalnya secara spontan siswa menjawab 2 permen dan 2 buah apel secara lisan kepada teman-teman di kelas. Contoh tersebut menunjukkan bahwa siswa sudah bisa melakukan operasi aljabar. Akan tetapi, siswa mengalami kesulitan pada saat diminta menuliskan penyelesaian dalam bentuk simbol.

Peneliti melakukan observasi pada tanggal 8 februari 2017 dan melakukan pengamatan secara acak kepada tiga siswa, jawaban yang ditampilkan masih terbilang kurang. Pertanyaannya, yaitu:

1) Hasil dari perkalian tiga oleh $x$ dikurangi empat adalah...

2) Hasil dari perkalian setengah oleh hasil dari jumlah antara $x$ dan 5 adalah...

3) Disebuah toko komputer terdapat 10 laptop, 5 komputer dan 3 speaker, pada suatu hari ada beberapa barang yang terjual yaitu 3 laptop dan 2 komputer, kemudian toko mendapatkan kiriman dari pabrik berupa 2 unit laptop, 2 komputer dan 5 speaker. Berapakah jumlah alat elektronik yang ada di toko sekarang? 
4) Hasil dari jumlah antara perkalian enam oleh c dan perkalian sebelas oleh ab dikurangi perkalian empat oleh a adalah...

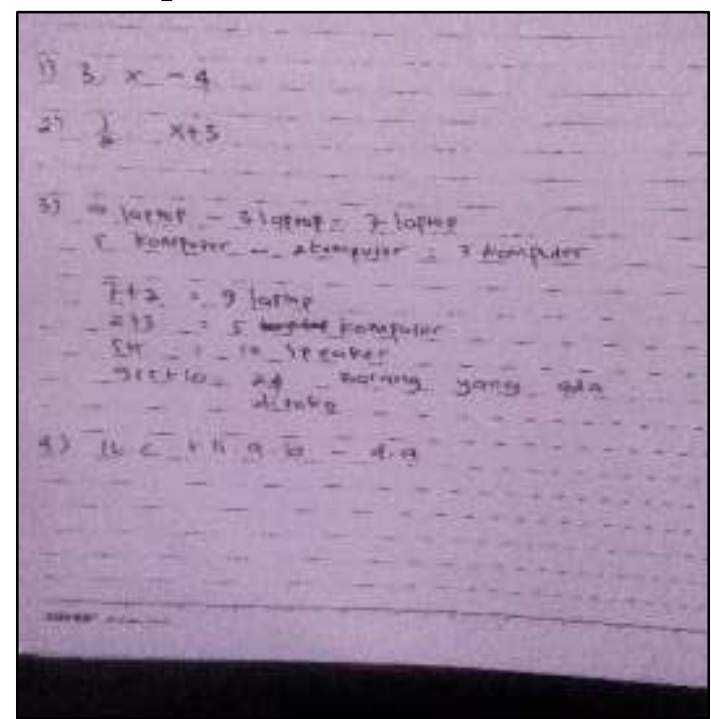

Gambar 1. Hasil Observasi terhadap Siswa Nomor 1

Berdasarkan gambar 1, siswa dapat menjawab semua soal, namun jawabannya masih belum sempurna. Pada soal nomor satu siswa menulis 3. $x$ - 4 secara pengertian jawaban ini tidak salah akan tetapi kurang sempurna. Karena siswa tidak paham jika 3. $x=3 x$. Untuk soal nomor dua sepertinya siswa kesulitan dalam menjawab soal tersebut. Pada soal nomor dua dapat dilihat bahwa siswa masih kurang dalam memahami konsep aljabar, siswa mendefinisikan bahwa $x+5=5 x$. Untuk soal nomor 3 siswa mampu memahami maksud dari pertanyaan, akan tetapi siswa menjawab pertanyaan tersebut dengan kata-kata sesuai pemahamannya, bukan dengan mengubah ke dalam bentuk ekspresi aljabar. Padahal pada soal, peneliti sudah memberi instruksi untuk menjawab soal ke dalam bentuk ekspresi aljabar, ini berarti siswa masih tidak memahami tentang konsep aljabar atau pun ekspresi aljabar. Untuk soal nomor empat kasusnya sama dengan soal nomor satu yaitu siswa tidak memahami bahwa 16.c = 16c. Soal nomor tiga dijawab dengan baik dan benar sesuai aturan yang ditentukan. Untuk jawaban nomor 1, 2, dan 4 terdapat kekeliruan dalam mengartikan soal. 


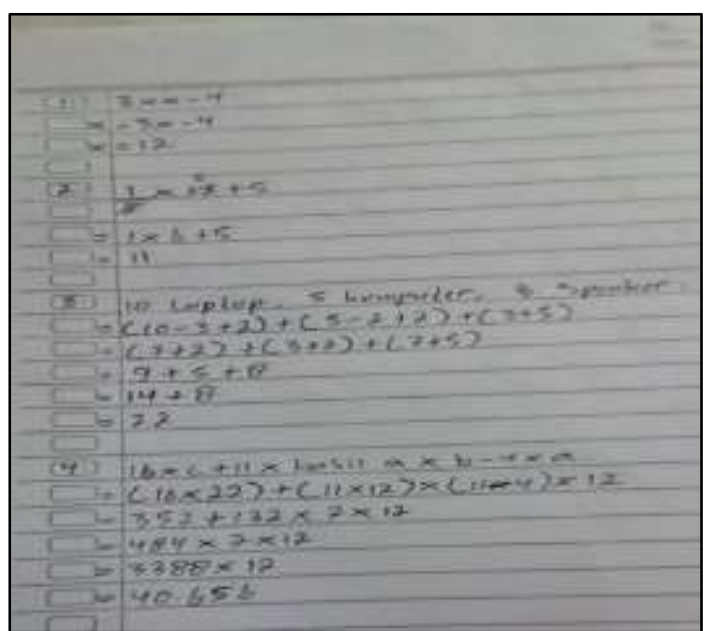

Gambar 2. Hasil Observasi kepada Siswa Nomor 3

Berdasarkan gambar 2, siswa dapat menjawab semua soal. Siswa nomor tiga juga menjawab soal nomor tiga dengan benar, siswa nomor tiga memahami maksud soal tersebut, akan tetapi tidak memahami bagaimana menggunakan ekspresi aljabar. Untuk soal nomor 1, 2, dan 4, siswa nomor 3 keliru dalam mengartikan soal. Siswa tersebut tidak memahami bagaimana cara menerjemahkan soal ke dalam bentuk ekspresi aljabar. Oleh karena itu, perlu dilakukan penelusuran lebih lanjut untuk mengetahui kemampuan siswa dalam menerjemahkan soal-soal tentang ekspresi aljabar berdasarkan kecerdasaan majemuk siswa. Tujuan dari penelitian ini adalah untuk menjelaskan kemampuan menerjemahkan ekspresi aljabar ditinjau dari kecerdasaan majemuk siswa SMP Negeri 15 Pontianak. Secara spesifik, tujuan penelitian dapat diperjelas dalam bahasan yang lebih sempit yaitu: (1) kemampuan menerjemahkan ekspresi aljabar ditinjau dari kecerdasan linguistik siswa SMP Negeri 15 Pontianak; (2) kemampuan menerjemahkan ekspresi aljabar ditinjau dari kecerdasan logika matematika siswa SMP Negeri 15 Pontianak; 3) kemampuan menerjemahkan ekspresi aljabar ditinjau dari kecerdasan visual-spasial siswa SMP Negeri 15 Pontianak; dan 4) kemampuan menerjemahkan eskpresi aljabar ditinjau dari kecerdasan interpersonal siswa SMP Negeri 15 Pontianak.

\section{METODE PENELITIAN}

Metode penelitian yang digunakan adalah jenis penelitian kualitatif, dengan rancangan penelitian studi kasus menggunakan pendekatan deskriptif. SMP Negeri 15 Pontianak dipilih sebagai lokasi penelitian, 
dikarenakan lokasi tersebut merupakan tempat peneliti menemukan permasalahan terkait menerjemahkan ekspresi aljabar. Adapun data yang digunakan dalam penelitian ini adalah data kuantitatif dan kualitatif. Data kuantitatif berupa skor angket pengukuran kecerdasan majemuk siswa, sedangkan data kualitatif berupa deskripsi jawaban siswa pada masingmasing jenis kecerdasan. Adapun yang menjadi sumber data adalah siswa kelas VII SMP Negeri 15 Pontianak. Peneliti sebagai instrumen utama terlibat penuh dalam proses penelitian. Untuk memperoleh data yang diinginkan, peneliti menggunakan teknik komunikasi tak langsung dan teknik pengukuran. Teknik komunikasi tak langsung yang digunakan berupa angket untuk mengetahui kecerdasan majemuk siswa. Selain itu, teknik pengukuran yang digunakan berupa tes untuk mengetahui kemampuan siswa dalam menerjemahkan bentuk ekspresi aljabar. Agar data yang diperoleh sesuai dengan tujuan penelitian, instrumen pendukung yang digunakan terlebih dahulu divalidasi dan diuji coba terutama tes essay yang dibuat. Hasil yang diperoleh disajikan pada tabel 1.

Tabel 1. Rangkuman Hasil Analisis Butir Soal

\begin{tabular}{|c|c|c|c|c|c|}
\hline & oal & Validitas & $\overline{D P}$ & TK & Keterangan \\
\hline \multirow{6}{*}{1.} & $\mathrm{a}$ & Cukup & Jelek & Sedang & \multirow{2}{*}{$\begin{array}{l}\text { Tidak layak } \\
\text { digunakan }\end{array}$} \\
\hline & $\mathrm{b}$ & Tinggi & Jelek & Mudah & \\
\hline & c & Tinggi & Minimum & Sedang & $\begin{array}{l}\text { Layak } \\
\text { digunakan }\end{array}$ \\
\hline & $\mathrm{d}$ & Rendah & Minimum & Sedang & $\begin{array}{l}\text { Tidak layak } \\
\text { digunakan }\end{array}$ \\
\hline & $\mathrm{e}$ & Cukup & Minimum & Mudah & \multirow{2}{*}{$\begin{array}{l}\text { Layak } \\
\text { digunakan }\end{array}$} \\
\hline & $\mathrm{f}$ & Tinggi & Minimum & Sedang & \\
\hline \multicolumn{2}{|l|}{2.} & Tinggi & Sangat baik & Sedang & $\begin{array}{l}\text { Layak } \\
\text { digunakan }\end{array}$ \\
\hline \multicolumn{2}{|l|}{3.} & Cukup & Jelek & Sedang & $\begin{array}{l}\text { Tidak layak } \\
\text { digunakan }\end{array}$ \\
\hline \multicolumn{2}{|c|}{4.} & Tinggi & Cukup baik & Sedang & \multirow{2}{*}{$\begin{array}{l}\text { Layak } \\
\text { digunakan }\end{array}$} \\
\hline \multicolumn{2}{|c|}{5.} & Cukup & Cukup baik & Sedang & \\
\hline
\end{tabular}

Keterangan:

DP : Daya Pembeda Soal

TK : Tingkat Kesukaran Soal 
Berdasarkan tabel 1, dapat disimpulkan bahwa dari kesepuluh soal yang diujicobakan terdapat 4 soal yang tidak layak digunakan, yaitu soal nomor $1 \mathrm{a}, \mathrm{b}, \mathrm{d}$, dan 3. Enam soal lainnya layak digunakan dalam penelitian, yaitu soal nomor 1 c, e, f, 2, 4 dan 5 . Koefisien reliabilitas soal sebesar 0,83 sehingga dapat dinyatakan bahwa soal tersebut memiliki reliabilitas sangat tinggi artinya layak digunakan. Prosedur analisis data menggunakan tahap yaitu: (1) reduksi, peneliti dapat melakukan pilihan-pilihan terhadap data yang akan diberi kode, membuang data yang tidak perlu dan mengambil data yang diperlukan, dan mengorganisasikan data sehingga kesimpulan akhirnya dapat diverifikasi; (2) penyajian data, dalam proses penyajian data, dapat ditampilkan secara sederhana dalam bentuk kata-kata, kalimat naratif, grafik, dan tabel. Dengan tujuan agar data dapat dengan mudah dipahami sebagai dasar dalam mengambil kesimpulan; (3) pengambilan keputusan atau verifikasi, pada kesimpulan akhir yang dibuat harus sejalan dengan fokus penelitian, tujuan penelitian, dan temuan penelitian yang sudah dilakukan.

\section{HASIL PENELITIAN DAN PEMBAHASAN}

Hasil perhitungan skor dari pengisian angket diperoleh klasifikasi kategori kecerdasan yaitu terdapat 1 siswa yang memiliki kecerdasan linguistik, 6 siswa dengan kecerdasan logika matematika, 2 siswa dengan kecerdasan visual-spasial, dan 14 siswa dengan kecerdasan interpersonal. Kecerdasan interpersonal siswa yang mendominasi pada kelas tersebut.

\section{a. Kecerdasan linguistik}

Kelompok siswa dengan kecerdasan linguistik nilai tertinggi yang diperoleh oleh kode NF21 dengan skor sebesar 22 dengan nilai 91,66. Siswa dengan kecerdasan linguistik dapat dikategorikan memiliki kemampuan yang bagus dalam menerjemahkan ekspresi aljabar, mampu mendefinisikan maksud dari setiap butir soal, menentukan langkah pengerjaan dan menyelesaikan soal dengan baik. Hal tersebut disebabkan oleh siswa yang memiliki kecerdasan linguistik cenderung mempunyai ingatan yang baik. Menurut Al-Findy (2014: 14), salah satu indikator yang dimiliki siswa dengan kemampuan linguistik adalah mempunyai ingatan yang kuat, sehingga dalam pengerjaan soal kemampuan ekspresi aljabar lebih detail. Akibatnya hasil menerjemahkan ekspresi aljabar lebih mudah dibaca oleh pembaca. Selain itu, ungkapan tersebut didukung oleh hasil penelitian Hasibuan (2019) menyatakan bahwa ada hubungan positif dan signifikan antara kecerdasan 
linguistik dengan hasil belajar matematika siswa sekolah menengah. Hal ini diperkuat dari hasil penelitian Fitriani, Aunurrohman, \& Cahyono (2018) yang menyatakan bahwa kecerdasan linguistik berpengaruh terhadap hasil belajar mahasiswa pada mata kuliah trigonometri. Hanya saja siswa masih kurang teliti dalam menjawab dan mencerna soal. Namun, karena hanya terdapat seorang siswa yang memiliki kecerdasan linguistik maka peneliti tidak memiliki bahan untuk dibandingkan, meskipun demikian siswa yang memiliki kecerdasan linguistik mampu mengerjakan soal dengan baik, dengan catatan serius dalam mendengarkan penjelasan guru, menggunakan waktu untuk mengerjakan soal dengan maksimal seperti yang dilakukan siswa dengan kode NF21. Selain itu, siswa ini juga dalam mengomunikasikan jawaban dari suatu soal cenderung lebih suka menambahkan simbol atau kata agar jawaban atau penjelasan yang siswa paparkan bisa lebih jelas.

\section{b. Kecerdasan logika matematika}

Terdapat 6 siswa dengan kecerdasan logika matematika. Dari 6 siswa hanya terdapat 2 siswa yang mencapai nilai KKM, terdapat beberapa penyebab nilai siswa dengan logika matematika rendah, yaitu siswa senang berbicara sendiri, tidak memaksimalkan waktu mengerjakan soal, tidak bersungguh-sungguh, menyepelekan penjelasan guru, malas mencatat, sering ke toilet, dan tidak adanya niat sungguh-sungguh untuk belajar. Namun, jika siswa dengan kecerdasan logika matematika serius dalam belajar, mendengarkan penjelasan guru, mencatat apa yang dicatat guru, bersungguhsungguh dalam mengerjakan soal, maka siswa dengan kecerdasan ini dapat mencapai nilai di atas KKM. Menurut Hamza B. Uno \& Masri Kuadrat dalam Al-Findy (2014), seseorang yang mempunyai kecerdasan logika matematika cenderung menyukai aktivitas berhitung dan memiliki kecepatan tinggi dalam menyelesaikan masalah matematika. Pengaruh lingkungan adalah penyebab kurang terasahnya kemampuan siswa, misalnya terganggu konsentrasi akibat mempunyai teman sebangku yang suka berbicara dan jail. Pada penelitian ini untuk kecerdasan logika matematika nilai tertinggi adalah skor 23 dengan nilai 95,8. Hasil yang diperoleh sangat memuaskan. Hal tersebut disebabkan oleh siswa yang memiliki kecerdasan logika matematika cenderung senang bekerja dengan angka-angka. Menurut Al-Findy (2014), salah satu indikator yang dimiliki siswa dengan kemampuan logika matematika adalah menyukai kelas matematika dan mampu berhitung dengan cepat. Artinya, siswa yang memiliki kecerdasan logika matematika memiliki kemampuan berhitung yang 
bagus, mampu memahami setiap soal dengan baik dan khususnya untuk materi ini siswa mampu mengerjakan soal kemampuan menerjemahkan ekspresi aljbar dengan nilai tertinggi dengan skor maksimal 23 dengan nilai 95,8. Hal tersebut didukung oleh hasil penelitian Epriliyanti \& Amin (2017) yang menyatakan bahwa kecerdasan visual-spasial memiliki pengaruh terhadap hasil belajar matematika siswa SMP sebesar 50,55\%.

\section{c. Kecerdasan visual-spasial}

Kelompok siswa dengan kecerdasan visual-spasial hanya memiliki 2 anggota di dalam kelas tersebut, satu siswa perempuan dan satu siswa lakilaki. Selisih poin yang diperoleh cukup banyak yaitu sebesar 7 poin. Ada beberapa faktor yang menyebabkan nilai yang diperoleh berbeda. Yang pertama, siswa dengan kode NF1 tidak menjawab semua soal yaitu soal nomor 4 tidak dikerjakan, sering terlihat mengobrol dengan teman sebangku, suka melamun, dan tidak memaksimalkan waktu pengerjaan. Hal-hal kecil seperti itu yang menyebabkan siswa mendapatkan nilai di bawah KKM.

Dari hasil pengamatan peneliti dari pengerjaan siswa, peneliti mendapat beberapa kemiripan dalam mengerjakan soal, yaitu pada soal nomor 1a, 1b, dan 2 dengan skor yang diperoleh sama. Namun, untuk mendapatkan kesimpulan yang lebih jelas peneliti mengambil soal nomor 2, mereka sama-sama mengerjakan soal hanya sampai sisa kain. Itu artinya, kedua siswa tersebut tidak memahami maksud dari soal dan tidak memahami apa yang ditanyakan. Peneliti menyimpulkan bahwa siswa dengan kecerdasan visual-spasial mempunyai pemikiran yang mirip dalam memahami soal khususnya dalam ekspresi aljabar. Jika siswa dengan kecerdasan visual-spasial bersungguh-sungguh dalam belajar, maka nilai tertinggi yang dapat diperoleh adalah skor 20 dengan nilai 83,33. Hasil yang diperoleh dikategorikan baik, itu artinya siswa dengan kecerdasan visual-spasial mampu mengerjakan soal kemampuan ekspresi aljabar dengan skor maksimal 20 dengan nilai 83,33. Hal tersebut didukung oleh hasil penelitian Epriliyanti \& Amin (2017) yang menjelaskan bahwa kecerdasan visual-spasial memiliki pengaruh terhadap hasil belajar matematika siswa SMP sebesar 50,55\%.

\section{d. Kecerdasan interpersonal}

Terdapat 14 siswa dengan kecerdasan interpersonal. Kecerdasan ini paling dominan anggotanya daripada 3 kecerdasan lainnya. Siswa dengan kecerdasan interpersonal cenderung memiliki kesalahan yang sama. Siswa 
yang memiliki kecerdasan interpersonal memiliki kemampuan baik dalam mengerjakan soal, hal ini dikarenakan siswa yang mencapai nilai KKM lebih dari setengah. Artinya, siswa yang mudah berinteraksi dengan orang lain cenderung lebih pandai dalam mengerjakan soal khususnya dalam materi ekspresi aljabar, karena dalam kegiatan pembelajaran antara guru dan siswa membutuhkan interaksi yang aktif untuk membantu proses kelancaran dalam pembelajaran. Dalam berinteraksi selalu menghasilkan sebab-akibat, misalnya siswa bertanya guru menjawab atau sebaliknya guru bertanya siswa menjawab, akibatnya pembelajaran cenderung tidak pasif. Interaksi tersebut dapat membantu perkembangan siswa. Dengan demikian kemampuan interpersonal seseorang memegang peran yang cukup penting.

Siswa yang memiliki kecerdasan interpersonal dapat mencapai nilai tertinggi pada skor 22 dengan nilai 91,66. Hasil yang diperoleh sangat memuaskan. Hal tersebut dikarenakan siswa yang cenderung memiliki kecerdasan interpersonal lebih leluasa dalam berinteraksi seperti tanya jawab terhadap teman maupun guru, sehingga informasi yang diperoleh lebih mudah. Sejalan dengan indikator kecerdasan interpesonal bahwa jika siswa harus menghafal, maka siswa tersebut cenderung meminta bantuan terhadap teman untuk menguji diri apakah sudah memahaminya atau tidak. Akibatnya jika memiliki kesalahan, maka siswa tersebut mendapat koreksi dari temannya, sehingga siswa lebih mudah menerima informasi karena siswa belajar bersama teman. Oleh sebab itu, siswa yang memiliki kecerdasan interpersonal dapat mengerjakan soal kemampuan menerjemahkan ekspresi aljabar dengan baik, sehingga skor maksimal yang mampu diperoleh sebesar 22 dengan nilai 91,66. Hal ini sejalan dengan penelitian Najamuddin, Idris, \& Afiif (2015) yang menjelaskan bahwa terdapat pengaruh yang signifikan pada kecerdasan interpersonal dan task comment terhadap hasil belajar matematika siswa MTs. Penelitian Fajriani \& Masni (2017) juga menjelaskan bahwa kecerdasan interpersonal berpengaruh positif terhadap hasil belajar matematika.

Nilai keseluruhan kemampuan siswa dalam menerjemahkan ekspresi aljabar ditinjau dari kecerdasan majemuk siswa rata-rata sebesar 65,18 termasuk dalam kategori kurang. Perlu diketahui bahwa manusia sejak lahir sudah memiliki delapan kecerdasan. Sebagaimana pendapat Garnder dalam Armstrong (2009) bahwa kecerdasan manusia dikelompokkan menjadi delapan kecerdasan yaitu linguistik, logika matematika, visual-spasial, interpersonal, intrapersonal, natural, musik, dan fisik. Kedelapan kecerdasan 
inilah yang mempengaruhi kemampuan siswa, khususnya dalam penelitian ini adalah menerjemahkan ekspresi aljabar. Nilai yang diperoleh berbeda-beda meskipun memiliki kecenderungan kecerdasan yang sama, karena kombinasi kecerdasan pada manusia satu dengan manusia lainnya berbeda-beda, kombinasi tersebutlah yang berperan dalam pengembangan kemampuan siswa. Sejalan dengan pendapat Gardner dalam Armstrong (2009) yang mengatakan bahwa kita semua begitu berbeda terutama karena kita semua memiliki kombinasi yang berbeda dalam kecerdasan. Jadi, dapat disimpulkan bahwa manusia satu dengan manusia lainnya tidak dapat disamakan tingkat kecerdasannya karena kombinasi yang ada di dalam diri manusia tersebut berbeda-beda sehingga meski memiliki kecenderungan kecerdasan yang sama tetapi tidak dapat dikategorikan memiliki kemampuan yang sama persis, tetapi juga memiliki kecenderungan pola pemikiran yang mirip.

Untuk mendapatkan hasil yang maksimal, peneliti juga melakukan diskusi kembali bersama teman sejawat, dalam hal ini adalah guru matematika. Sebab, bertanya kepada ahli akan membuat peneliti semakin yakin akan kesimpulan yang telah dipaparkan sebelumnya. Adapun hasil dari diskusi sebagai berikut:

1. Bahwa yang membuat kemampuan siswa tidak maksimal adalah siswa tidak mendengarkan penjelasan guru, berbicara sendiri.

2. Malas mencatat, catatan tidak rapi dan lengkap

3. Posisi duduk juga mempengaruhi, seharusnya posisi duduk siswa diatur oleh wali kelas agar siswa yang sering berbicara disandingkan dengan siswa yang pendiam, agar kondisi kelas lebih kondusif.

4. Dari hasil deskripsi empat kecerdasan diperoleh bahwa siswa dengan kemampuan linguistik sudah mampu untuk mamahami maksud dari setiap butir soal, memahami langkah pengerjaan, hanya saja kurang teliti. Siswa dengan kecerdasan logika matematika juga mampu dengan baik dalam mengerjakan soal, memahami setiap soal yang diberikan, paham langkah apa yang digunakan, dan mampu menyelesaikan dengan baik setiap pengerjaan dengan catatan benar-benar serius dalam mengerjakannya. Siswa yang memiliki kecerdasan visual-spasial mempunyai kemiripan dalam menjawab soal, mempunyai pemahaman yang hampir sama dalam mendefinisikan soal, dan mampu mencapai nilai yang baik jika bersungguh-sungguh dalam belajar, sedangkan siswa yang memiliki kecerdasan interpersonal memiliki kemiripan 
dalam berpikir dan mengerjakan soal, kecerdasan interpersonal cenderung memiliki letak kesalahan yang sama.

Dari uraian di atas, dapat dilihat bahwa meskipun setiap siswa memiliki kecerdasan yang berbeda, mereka masih bisa memperoleh nilai yang memuaskan dalam mengerjakan soal matematika, khususnya materi ekspresi aljabar.

\section{SIMPULAN}

Nilai rata-rata siswa dalam mengerjakan soal kemampuan menerjemahkan ekspresi aljabar ditinjau dari kecerdasan majemuk siswa sebesar 65,18 dan termasuk dalam kategori kurang. Nilai maksimal dapat diperoleh dalam mengerjakan soal kemampuan menerjemahkan ekspresi aljabar dari kecerdasan linguistik sebesar 91,66 dan termasuk dalam kategori sangat baik. Siswa dengan kecerdasan linguistik dapat dikategorikan memiliki kemampuan yang baik dalam menerjemahkan ekspresi aljabar, mampu mendefinisikan maksud dari setiap butir soal, menentukan langkah pengerjaan dan menyelesaikan soal dengan baik, hanya saja masih kurang teliti dalam menjawab dan mencerna soal. Nilai maksimal dapat diperoleh dalam mengerjakan soal kemampuan menerjemahkan ekspresi aljabar dari kecerdasan logika matematika sebesar 95,8 termasuk dalam kategori sangat baik. Nilai maksimal dapat diperoleh dalam mengerjakan soal kemampuan menerjemahkan ekspresi aljabar dari kecerdasan visual-spasial sebesar 83,33 dan termasuk dalam kategori baik. Siswa dengan kecerdasan visual-spasial mempunyai pemikiran yang mirip dalam memahami soal, khususnya dalam ekspresi aljabar. Nilai maksimal dapat diperoleh dalam mengerjakan soal kemampuan menerjemahkan ekspresi aljabar dari kecerdasan interpersonal sebesar 91,66 dan termasuk dalam kategori sangat baik. Siswa yang memiliki kecerdasan interpersonal memiliki kemampuan yang baik dalam mengerjakan soal, dapat dilihat bahwa siswa mencapai nilai KKM. Artinya, siswa yang mudah berinteraksi dengan orang lain cenderung lebih pandai dalam mengerjakan soal, khususnya dalam materi ekspresi aljabar.

\section{DAFTAR PUSTAKA}

Al-Findy, K. Z. (2014). Metode pembelajaran pendidikan agama islam berbasis multiple intelligences. Jakarta: Pustaka Zakiyya.

Armstrong, T. (2009). Multiple intelligences in the classroom (3rd ed.). Beauregard St: Alexandria. Retrieved from: https://books.google.co.id/books/abo 
ut/Multiple_Intelligences_in_the_Classroom.html?id=zCdxFRFmXpQC \&redir_esc $=y$.

Asyrofi, M., \& Junaedi, I. (2016). Kemampuan representasi matematis ditinjau dari multiple intellingence pada pembelajaran hybrid learning berbasis konstruktivisme. Unnes Journal of Mathematics Education Research, 5(1), 32-39.

Desy, T. A. (2016). Kemampuan siswa dalam menerjemahkan ekspresi aljabar di kelas VIII MTs Darul Khairat Pontianak. Skripsi. IKIP PGRI Pontianak. Retrieved from: http://digilib.ikippgriptk.ac.id/id/eprint/ 411.

Epriliyanti, L. W., \& Amin, S. M. (2017). Pengaruh kecerdasan logis matematis dan spasial-visual terhadap hasil belajar matematika siswa smp. MATHEdunesa: Jurnal Ilmiah Pendidikan Matematika, 2(6), 123-130. Retrieved from: https://jurnalmahasiswa.unesa.ac.id/index.php/math edunesa/article/view/19746.

Fajriani, \& Masni, E. D. (2017). Pengaruh kecerdasan interpersonal terhadap hasil belajar matematika siswa. Pedagogy: Jurnal Pendidikan Matematika, 2(1), 63-73. Retrieved from http://journal.uncp.ac.id/index.php/Peda gogy/article/view/661.

Fitriani, U., Aunurrohman, A., \& Cahyono, B. (2018). Pengaruh kecerdasan linguistik terhadap kemampuan koneksi matematis dalam menyelesaikan masalah open ended materi trigonometri. Phenomenon: Jurnal Pendidikan MIPA, 08(1), 101-113. Retrieved from: http://journal.walisongo.ac.id/index.php/Phenomenon/article/view/ $2549 / 1748$.

Hasibuan, M. F. (2019). Hubungan kecerdasan linguistik dengan hasil belajar matematika siswa kelas XI SMA Taman Siswa Lubuk Pakam. Journal of Computer Networks, Architecture and High Performance Computing, 1(1), 41-48. Retrieved from https://iocscience.org/ejournal/index.php/CN APC/article/view/44/35.

KBBI, T. R. (2008). Kamus besar bahasa Indonesia (Edisi Keempat). Jakarta: Pusat Bahasa Departemen Pendidikan Nasional. https:/ / doi.org/10.11113/jt. v56.60.

Krismanto R, A. (2009). Kapita selekta pembelajaran aljabar di kelas VII SMP. Jakarta: PPPPTK Matematika. https://doi.org/10.1017/CBO97811074153 24.004 .

Najamuddin, N., Idris, R., \& Afiif, A. (2015). Pengaruh kecerdasan interpersonal dan taks commiment terhadap hasil belajar matematika siswa kelas VIII MTS Negeri Balang-Balang Kabupaten Gowa. MaPan : Jurnal Matematika Dan Pembelajaran, 3(2), 163-176. https://doi.org/10.24 252/MAPAN.2015V3N2A3. 